\title{
Convection-enhanced delivery to the central nervous system
}

\author{
Russell R. Lonser, MD, ${ }^{1,2}$ Malisa Sarntinoranont, PhD, ${ }^{3}$ Paul F. Morrison, PhD, ${ }^{4}$ \\ and Edward H. Oldfield, MD ${ }^{2,5}$
}

\begin{abstract}
1Department of Neurological Surgery, Ohio State University Wexner Medical Center, Columbus, Ohio; ${ }^{2}$ Surgical Neurology Branch, National Institute of Neurological Disorders and Stroke; ${ }^{4}$ Biomedical Engineering and Physical Science Resource, National Institute of Biomedical Imaging and Bioengineering, National Institutes of Health, Bethesda, Maryland; ${ }^{3}$ Department of Mechanical and Aerospace Engineering, University of Florida, Gainesville, Florida; and ${ }^{5}$ Department of Neurological Surgery, University of Virginia Health Sciences Center, University of Virginia, Charlottesville, Virginia
\end{abstract}

\begin{abstract}
Convection-enhanced delivery (CED) is a bulk flow-driven process. Its properties permit direct, homogeneous, targeted perfusion of CNS regions with putative therapeutics while bypassing the blood-brain barrier. Development of surrogate imaging tracers that are co-infused during drug delivery now permit accurate, noninvasive real-time tracking of convective infusate flow in nervous system tissues. The potential advantages of CED in the CNS over other currently available drug delivery techniques, including systemic delivery, intrathecal and/or intraventricular distribution, and polymer implantation, have led to its application in research studies and clinical trials. The authors review the biophysical principles of convective flow and the technology, properties, and clinical applications of convective delivery in the CNS.
\end{abstract}

http://thejns.org/doi/abs/10.3171/2014.10.JNS14229

KEY WORDS convection-enhanced delivery; drug delivery; central nervous system; technique; bulk flow

$\mathrm{B}$ ASED on the rapid progression in understanding the precise pathobiology underlying various neurological diseases, a number of promising new putative therapeutics have been developed for specific disorders that have been ineffectually treated or are not currently treatable. While these agents have been successful in reversing disease-related pathology in vitro and/or in animal models, they have not been successfully translated into clinically effective therapies. One of the largest obstacles to the successful conversion of putative therapeutics into effective treatments is the inability to deliver these agents past the CNS blood-brain barrier (BBB) in a reliable, targeted, and homogeneous way using currently available approaches for drug delivery, including systemic delivery, intrathecal and/or intraventricular distribution, and polymer implantation. $6,15,47,67,80$

To surmount the limitations of available CNS drug delivery techniques, targeted direct perfusion of regions of the nervous system using the convection-enhanced delivery (CED) of infusate is increasingly used in research models of neurological disease and in clinical trials to treat neurological disorders. Because infusate is driven by a hydrostatic pressure differential (bulk flow), ${ }^{7,67} \mathrm{CED}$ can be used to bypass the BBB and distribute putative therapeutics to targeted regions. Further, convective bulk flow properties allow for homogeneous and reproducible perfusion of variably sized regions of the nervous system using compounds with a wide range of molecular weights. The development of co-infused surrogate imaging tracers now permits noninvasive real-time monitoring of convective delivery. We review the biophysical principles of convective flow and the technology, properties, and clinical applications of convective delivery in the CNS.

\section{Biophysical Principles of Convective Flow}

Within the extracellular space of the CNS, fluids and agents move either by diffusion or by bulk flow. Diffusive flux $(\mathrm{J})$ depends on the concentration gradient $(\nabla C$, where $\nabla$ is the gradient operator), as stated by Fick's law, $\mathrm{J}$ $=-\mathrm{DVC}$, where tissue diffusivity $(\mathrm{D})$ is highly dependent on the molecular weight of the molecule. Unfortunately, effective diffusion times are long for macromolecular therapeutic agents, and transport depends on large concentration gradients, often requiring unacceptably high

ABBREVIATIONS BBB $=$ blood-brain barrier; $\mathrm{CED}=$ convection-enhanced delivery.

SUBMITTED January 29, 2014. ACCEPTED October 7, 2014.

INCLUDE WHEN CITING Published online November 14, 2014; DOI: 10.3171/2014.10.JNS14229.

DISCLOSURE The authors report no conflict of interest concerning the materials or methods used in this study or the findings specified in this paper. Dr. Lonser holds a patent with $\mathrm{NIH}$. 
concentrations near the drug source. As a result, extensive distribution by diffusion is not possible for macromolecular therapeutic agents of interest for most disorders, and practically, diffusive penetration in brain tissue is generally limited to a few millimeters. ${ }^{67}$

Bulk flow is extracellular fluid flow that can exist under either normal or abnormal (for example, edema) ${ }^{1}$ conditions. Within the CNS, these flows can be modeled by treating tissue as a hydrated porous medium consisting of fluid and solid phases, in which the fluid phase is the interconnected interstitial space and the solid phase is the aggregation of cellular, vascular, and extracellular matrix constituents. Bulk flow is driven by fluid pressure gradients that exist within tissues and can be modeled by Darcy's law, which asserts that the velocity of fluid (v) is directly related to the tissue pressure gradient $(\nabla p): \mathrm{v}=$ $-\mathrm{K} \nabla p$, where hydraulic conductivity $(\mathrm{K})$ is a measure of flow conductance. Compared with diffusion, bulk flows are largely independent of molecular weight.

In CED, a cannula is discretely introduced directly into the nervous system interstitial spaces with its tip at the target site. Controlled infusions induce bulk flows, which distribute infusate over large volumes within the extracellular space and are capable of achieving multicentimeter depths of penetration. During CED, transport to surrounding tissue depends on bulk flow, as well as diffusion and clearance loss due to permeation and reaction. The balance between these sources and sinks determines the overall penetration distance. Theories for CED at a constant infusion rate into homogeneous brain tissues provide the simplest possible expression to describe concentration profiles and penetration distances. In this model, interstitial bulk velocity $(v)$ varies radially around a spherical cannula source and is solved using the continuity equation (differential mass balance of water in brain tissue) and Darcy's law: $v(r)=q /\left(4 p r^{2}\right)$, where $q$ is the infusion flow rate and $r$ is the radius from the cannula tip. More complex analytical solutions for infusion from a cannula source have also been developed that account for water uptake in tissue ${ }^{70}$ and tissue swelling with pressurization..$^{5,17,85,103}$

Tissue transport of the infused species is described by a differential mass balance relation governing tissue concentration as a function of space and time, which is formulated to account for convection, diffusion, metabolism, binding, and net transport across the microvasculature: $\partial \mathrm{C} / \partial \mathrm{t}=\mathrm{D} \nabla^{2} \mathrm{C}-\nabla(\mathrm{vC} / f)-\mathrm{k}_{\mathrm{m}} \mathrm{C} / f-\mathrm{P} \times \mathrm{s}\left(\mathrm{C} / f-\mathrm{C}_{\mathrm{p}}\right)$, where $\mathrm{k}_{\mathrm{m}}$ is the first-order metabolic rate constant in tissue (the rate of degradation), $f$ is the fluid volume fraction (porosity), $C_{p}$ is the plasma concentration of infused solute (usually 0 ), and $\mathrm{P} \times \mathrm{s}$ is the product of permeability coefficient and surface area per volume of tissue that accounts for the passive movement of infusate across vessels. When needed, $f$ can be replaced by another constant accounting for weak binding of infusate species to tissue components. ${ }^{68}$ This equation is generally solved numerically.

Simulations for nonbinding $180-\mathrm{kD}$ macromolecules delivered at $3 \mu \mathrm{l} / \mathrm{min}$ from a spherical source into homogeneous tissue are associated with radial penetrations of $1.5 \mathrm{~cm}$ in 12 hours with relatively flat and uniform profiles ("square-shaped" concentration profile) that decline dramatically at the advancing front (Fig. 1). ${ }^{67,69}$ Initially, trans-

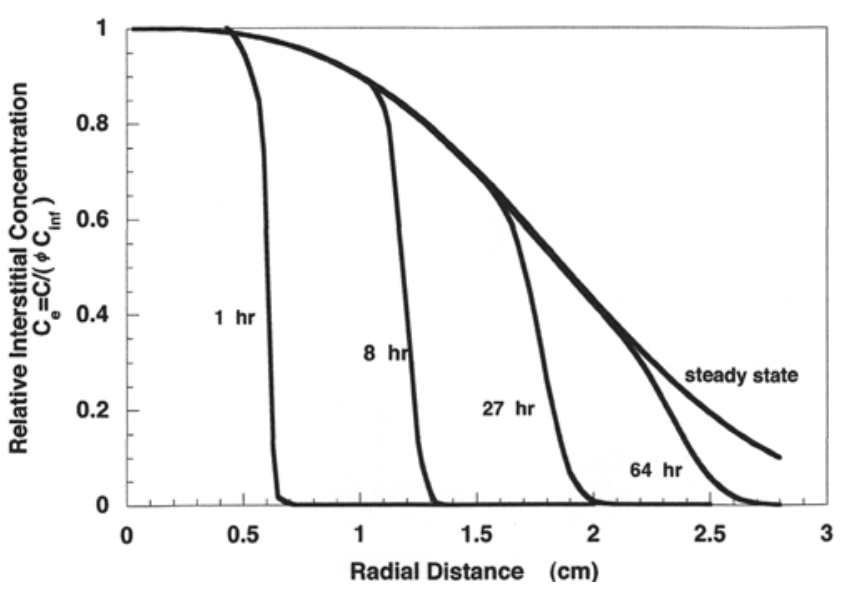

FIG. 1. Convection-enhanced delivery interstitial concentration profiles for a $180-\mathrm{kD}$ macromolecule in nonbinding brain tissue. Simulations are for varying times during infusion at $3 \mu \mathrm{l} / \mathrm{min}$ and include drug degradation (33 hours characteristic time for degradation), cannula geometry (32 gauge), and tissue and vascular transport properties as listed in Morrison, 2001.

port is dominated by convection, and the advancing front approximates a step function. With time, the steepness and bluntness of the advancing front decreases because of the superimposed contributions of diffusion and clearance. After the cessation of infusion, further transport of the drug will occur through tissue by continued convection (as long as a pressure gradient from the infused region persists) and by diffusion until clearance mechanisms clear the drug entirely from tissue. This phase should be considered in any dose-response estimation.

Recently, Sarntinoranont and colleagues ${ }^{100-102}$ developed an integrated finite element formalism model that can be used to optimize the distribution of substance $\mathrm{P}$-associated protein toxin to the spinal cord for chronic neuropathic pain treatment. This model accounts for the anisotropic transport in the spinal cord, the anatomical boundaries throughout the spinal cord substance, as well as substance $\mathrm{P}$-associated protein toxin binding/uptake, metabolism, and dose response. Further, groups have used computational analyses based on diffusion tensor imaging (an MRI technique that measures the restricted diffusion of water in nervous system tissues and measures axonal alignment) that account for preferential fluid flow and diffusion transport directions, which can vary in the extracellular spaces within complex nervous system anatomical structures. ${ }^{39,40,55,89,101}$

\section{Convective Delivery Technology Infusion Apparatus}

Direct transmission of a small controlled pressure differential is required for the steady flow of infusate into the extracellular CNS spaces. Constant and reliable pressure transmission during infusion demands a noncompliant infusion system. To minimize compliance in the infusion apparatus and reduce infusate binding, infusate reservoirs, tubing, and cannula are derived from noncompliant materials, including silicate, hardened plastic, and metals. The 
minimization or elimination of system compliance allows precise delivery of the infusate in either continuous or bolus convective flow patterns. Large-animal (primate) data indicate that that convective distribution of the infusate in the CNS is similar, feasible, and safe using either flow pattern if a noncompliant system is utilized. ${ }^{74}$

\section{Infusion Cannula}

Mathematical modeling, preclinical animal data, and clinical data indicate that the infusion cannula design affects the success of convective delivery to the CNS by reducing infusate leakback around the cannula at higher infusion rates and by eliminating intraparenchymal air entrainment (associated with catheters with an inner stylet) during insertion..$^{14,41,68,90,114}$ Specifically, the minimization of cannula tip diameter, which reduces tissue expansion, is a way to minimize leakback during infusion and has been demonstrated by mathematical modeling and animal data. ${ }^{68}$ Further, avoiding entrainment of intraparenchymal air that occurs with malleable infusion catheters upon removal of the rigid inner stylet needed for accurate placement of the tip is necessary to avoid preferential distribution in the tissue air pocket. These critical cannula properties have been achieved through the development of inner infusate cannula-outer guide cannula combinations, ${ }^{22,31,62}$ hollow fiber tubes,${ }^{77,78}$ as well as step-design cannulae. ${ }^{41,54}$

\section{Properties of Convective Delivery Bypassing the BBB}

Because putative therapeutics are perfused directly into the CNS using CED, the delivery of infusate bypasses the BBB. Further, the compounds that do not cross the $\mathrm{BBB}$ are the ideal agents to distribute via CED. Therapeutic compounds that do not readily penetrate the BBB from the systemic circulation, when delivered by convection, remain sequestered on the abluminal side of the BBB within the perfused parenchyma for prolonged periods until they are metabolized and cleared from the interstitial spaces., $75,21,60,69$ Consequently, large-molecular-weight (> $400 \mathrm{D})$ and/or hydrophilic compounds are best for CED in the CNS. In contrast, small-molecular-weight lipophilic agents readily leak from the perfused CNS tissues into the systemic circulation and thus have limited distribution distances with CED.

\section{Targeted Delivery}

Because infusate is distributed directly into site-specific regions of the CNS from an infusion cannula, the distribution of therapeutic agents is targeted. Previous studies have demonstrated that deep brain nuclear targets can be selectively perfused with small- and large-molecular-weight compounds (Fig. 2) ${ }^{32,54,57}$ Moreover, large-animal data indicate retrograde or anterograde transport of delivered therapeutics, including proteins, and transgene expression of products delivered by viral capsids or bacteriophage can be distributed from the perfused CNS region to other distant nonperfused regions via interconnecting white matter tracts in a highly predictable manner. ${ }^{20,38,42,54}$ These features of CED in the CNS permit manipulation
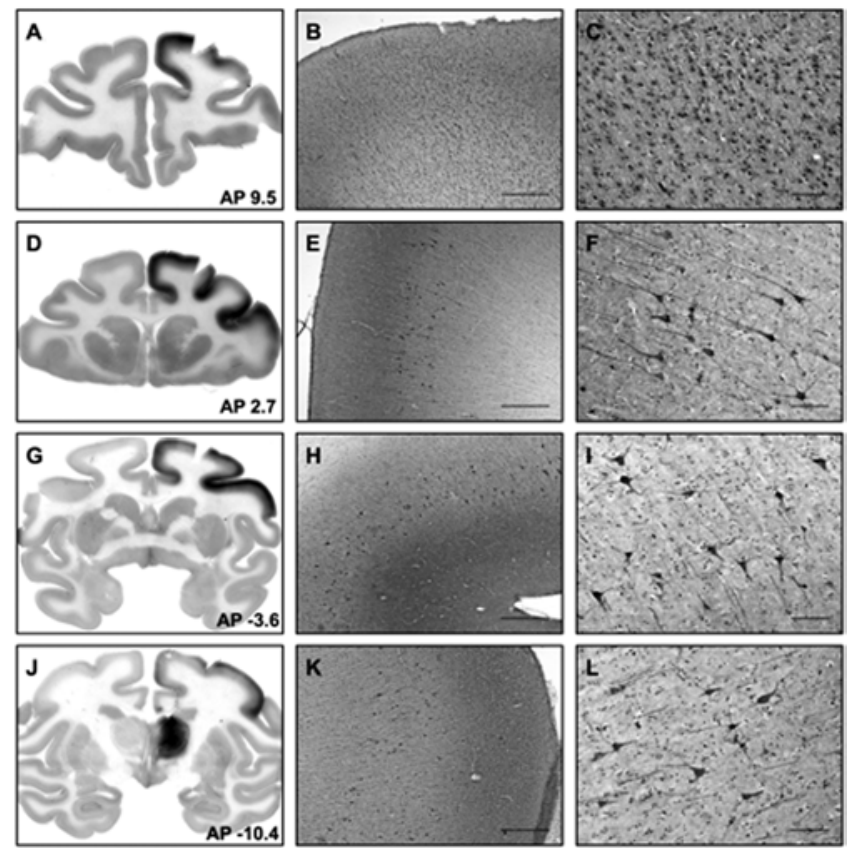

FIG. 2. Glial-derived neurotrophic factor (GDNF) protein distribution after thalamic infusion of adeno-associated virus Type 2 serotype (AAV2)GDNF. Immunohistochemical staining demonstrates GDNF expression in the prefrontal cortex on the same side as thalamic infusion of AAV2-GDNF (A). Cortical neurons positive for GDNF were found in the prefrontal cortex (Areas 9 and 10, B and C). Premotor cortex, frontal eye field, Broca's area, cingulate cortex neurons (D-G), as well as neurons of laminae $V$ and $V I$ in premotor cortex ( $E$ and $F$ ) and frontal eye fields ( $\mathrm{H}$ and I) were GDNF-positive. The GDNF-positive neurons were evident above the pyramidal neurons in cortical layers. GDNF-positive neurons were found at the infusion site in the thalamus $(\mathrm{J})$, as well as the cortical neurons in the somatosensory and motor cortex. Laminae $\mathrm{V}$ and $\mathrm{VI}$ of the somatosensory cortex neurons were also GDNF-positive ( $\mathrm{K}$ and $\mathrm{L}$ ). $\mathrm{AP}=$ anterior-posterior distance (in $\mathrm{mm}$ ) from the bregma. Numbers indicate different cortical areas referenced in the text. Bar $=5 \mathrm{~mm}(A, D$, $\mathrm{G}$, and J); $500 \mu \mathrm{m}$ (B, E, H, and K); $100 \mu \mathrm{m}$ (C, F, I, and L). Reproduced from Kells et al.: Proc Natl Acad Sci U S A 106:2047-2411, 2009.

of precisely targeted regions or regulation of broader anatomical regions via upstream or downstream effects of infusate delivery.

\section{Homogeneous Distribution}

Unlike diffusion-driven distribution, which results in limited tissue penetration from the diffusive surface (1 to $2 \mathrm{~mm}$ ) and a steep drop-off in concentration over that distance (250- to 1000 -fold decrease), ${ }^{6,105}$ bulk flow of the infusate during CED permits homogeneous distribution of infusate throughout a perfused tissue region. Autoradiographic analysis of infusate distribution in a large-animal brain, brainstem, spinal cord, and peripheral nerve demonstrates the homogeneity of convective delivery. $7,58,63,72$ Analysis of the distribution of radiolabeled compounds in animals euthanized immediately after completing a brief infusion via CED demonstrates a homogeneous "squareshaped" distribution pattern in gray and white matter consistent with a uniform high concentration of infusate over a perfused CNS region. Thus, biological and pharmacological effects that depend on the concentration of a 
molecule of interest exceeding a certain threshold can be precisely targeted.

\section{Reproducible Distribution}

Convective delivery in the CNS is reliable. Because convective distribution of an infusate occurs in the interstitial space, the distribution volume achieved by CED of a given infusate volume is inversely proportional to the size of the extracellular space available in the target tissue. Specifically, greater tissue distribution (per infusion volume) occurs in regions of the CNS with a smaller interstitial space. Alternatively, infusion into CNS regions with an expanded extracellular space (for example, regions with vasogenic edema) results in a reduction in the volume of tissue distribution (per infusion volume). ${ }^{62,116}$ Distribution volume to infusion volume ratios in naïve gray or white matter of the brain, spinal cord, and peripheral nerves range from $4: 1$ to $7: 1.3,22,54,58,63$ Perfusion into the tightly compacted white matter fibers of the brainstem is associated with larger distribution volume to infusion volume ratios, generally in the range of 6:1 to $10: 1 .^{60,72,99}$ This property of CED allows large, clinically relevant volumes of CNS tissue to be perfused relatively rapidly.

\section{Clinically Relevant Distribution}

Small or large clinically relevant volumes of perfusion are possible with convective delivery in the CNS. While convective perfusion of nuclear targets is feasible during an acute infusion (over minutes to hours), ${ }^{53,57,93}$ prolonged infusion can be used to completely perfuse significant regions of a cerebral hemisphere, the brainstem, and the spinal cord (Fig. 3). ${ }^{48,61}$ A significant limitation of other conventional delivery techniques is the inability to distribute drug in high concentrations in a targeted manner over large regions of the CNS. Because CED relies on bulk flow to move small- and large-molecular-weight infusate throughout the nervous system, large regions of nervous system structures can be perfused with drug in a relatively short period of time, provided that the drug is not too rapidly cleared. This property permits treatment of large regional disorders.

\section{Anisotropic and Isotropic Flow Patterns}

While distribution of infusate in gray matter is isotropic (approximating a spherical distribution pattern around the tip of the infusion cannula), convective distribution of infusate into white matter is anisotropic and occurs preferentially along parallel white matter tracts. ${ }^{14,58,63}$ The preferential infusate flow along white matter tracts can be exploited to fill large regions of white matter from a single infusion point source..$^{44,49,61}$ Specifically, infusion in the cerebral white matter tracts (for example, corona radiata) can be used to rapidly fill regions of the cerebral hemisphere and immediately subjacent cortical gray matter from a single infusion cannula. ${ }^{61}$ Similarly, convective infusion into the parallel lateral corticospinal tracts results in perfusion over several segments of the spinal cord..$^{58}$

\section{Effects of Anatomical Boundaries \\ Convective tissue perfusion efficiency near pial and}

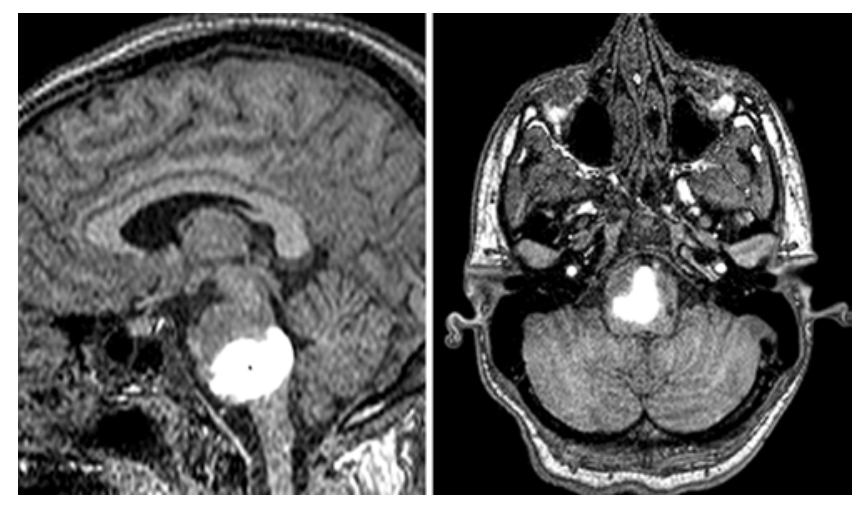

FIG. 3. Magnetic resonance imaging of interleukin-13 Pseudomonas exotoxin co-infused with a surrogate imaging tracer (Gd-DTPA) in a patient with a diffuse intrinsic pontine glioma. Left: Sagittal T1-weighted MR image demonstrating perfusion of a large region of the pons. Right: Axial T1-weighted MR image demonstrating perfusion of the pons in the same patient.

ependymal surfaces can be adversely affected once the leading edge of infusion meets these anatomical surfaces. Primate and clinical infusion data demonstrate that once the leading edge of a convective infusion encounters a pial or ependymal surface, the tissue distribution volume to infusion volume ratios decline as leakage of the infusate (small and large molecular weight) into the CSF of the cistern or ventricle occurs. ${ }^{36}$ Once infusate begins to cross these surfaces, a portion of the total infusate is lost into the CSF and is not distributed to tissue, reducing the distribution. The distribution volume will continue to decline compared with the distribution that would otherwise occur as a larger portion of the infusion volume encounters a pial or ependymal surface and a larger fraction of the total infusate is lost to the CSF space.

\section{Application Over a Wide Range of Compounds}

Convection-enhanced delivery permits the distribution of compounds with a wide range of molecular weights in the CNS. Convective delivery has been used to deliver small compounds $(<1 \mathrm{kD})$, including chemotherapeutic agents, amino acids, and low-molecular-weight imaging tracers. Alternatively, CED has been used to distribute proteins, virus and/or virus-sized particles, liposomes, and nanoparticles. ${ }^{24,33,42,106}$ While small- and most large-molecular-weight compounds will distribute by convective flow in a similar manner, viruses, virus-sized particles, and nanoparticles have restricted flow (tissue distribution volume to infusion volume ratio of 2:1 to $3: 1){ }^{13,42,106}$ This reduction in delivery efficiency is attributed to limits in the size of the extracellular space in the CNS, which has been estimated to be on the order of $100 \mathrm{~nm},{ }^{75,108}$ and to certain features of the infused nanoparticle. ${ }^{42}$

\section{Imaging of Convective Distribution}

Use of co-infused surrogate imaging tracers to track convective distribution in real time provides an opportunity to increase the effectiveness and safety of CED, to permit reliable assessment of therapeutic efficacy (by confirming successful delivery and distribution), and to better 
define the properties of CED in the CNS. Preclinical data demonstrate that CT and MRI tracers can be co-infused to accurately assess convective infusate distribution (Fig. 3). $3,16,22,25,27,29,59,76,106$ Because CED relies on bulk flow and because most large- and many small-molecular-weight compounds distribute at a similar rate during the typical time course of CED, surrogate tracers that differ substantially in size from the putative therapeutic can often be used to track drug distribution over infusion volumes necessary to treat many neurological disorders.

There are small-molecular-weight $(<1 \mathrm{kD})$ contrast agents for CT and MRI that are approved for clinical use and that can be used as surrogate tracers to track distribution during CED. Real-time imaging of CED is possible and has been used safely in animal and clinical trials to track small- and large-molecular-weight therapeutic compounds. . $^{3,18,59,110}$ While the small-molecule surrogate imaging tracers iopamidol and Gd-DTPA will accurately track large therapeutic compounds over infusate volumes sufficient to perfuse discrete disease-specific regions, the use of these surrogate tracers for tracking macromolecular distribution over large volumes and with prolonged infusion times will not accurately reflect the distribution of the drug, because of the tracer's long-term clearance by microvascular efflux and the long-term diffusional broadening associated with its low molecular weight.

In the case of the CT contrast agent iopamidol, experiments have shown that this small-molecule surrogate tracer accurately provides estimates of dextran $(70 \mathrm{kD})$ distribution volumes (that is, less than $20 \%$ difference between imaged and actual distribution volumes) provided that infusion rates $\left(\mathrm{q}_{\mathrm{i}}\right)$ are not too slow for a given total infusion volume $\left(\mathrm{V}_{\mathrm{i}}\right){ }^{22}$ For these specific compounds, modeling has shown that for a desired $\mathrm{V}_{\mathrm{i}}$ (in $\mu \mathrm{l}$ ), $\mathrm{q}_{\mathrm{i}}$ (in $\mu \mathrm{l} / \mathrm{min}$ ) must be chosen so that $\mathrm{q}_{\mathrm{i}} \geq \mathrm{V}_{\mathrm{i}} / 600$. From such empirical relationships, it is likely that many neurological disorders can be investigated with the expectation that the infusate volume required would be accurately tracked using a small-molecular-weight contrast agent-provided that the therapeutic compound, large or small, is negligibly reactive and confined to the extracellular space.

Because CED relies on infusate delivery into the interstitial spaces of the CNS, T2- and diffusion-weighted realtime MRI has been used to track drug distribution. ${ }^{88,91,98}$ Qualitative T2- and diffusion-weighted changes have been shown surrounding the infusion cannulae and areas of infusate distribution in these studies. Nevertheless, when qualitative autoradiographic assessment of the accuracy of the T2- and diffusion-weighted sequences was performed, ${ }^{35}$ it was revealed that these MRI sequences significantly underestimated the distribution of both small and large molecules. Specifically, these imaging techniques underestimated the volume of distribution of small- (sucrose) and large- (albumin) molecular-weight distribution using CED by $49 \%-60 \%$. $^{35}$

\section{Safety of Convective Delivery}

Increasing the fluid content of the interstitial space leads to edema in the perfused region. Previous studies have shown, however, that even when $180 \mu \mathrm{l}$ was infused into a rat brain over 2 hours (a volume sufficient to fill more than an entire rat hemisphere), intracranial pressure never rose above $8 \mathrm{~mm} \mathrm{Hg.9}$. While brain edema in eloquent areas can cause transient neurological symptoms, the deficits are reversible if intracranial pressure is maintained in the normal range and the vascular supply to the brain is not impaired ${ }^{86}$ Since intratissue pressure remains in the normal range with CED, the infusion of large volumes (even with near hemisphere filling) has no effect on blood flow to the perfused regions. This explains why permanent neurological injury has not occurred as a result of large-volume infusions. These clinical findings are also confirmed by histological studies showing no tissue damage in infused regions after CED.

It is possible that convective delivery could cause expansion of the interstitial space and symptomatic edema infusion at high rates, prolonged infusion (for example, chronic infusions), and infusion of very large volumes (for example, holohemispheric). The excess fluid, especially with rapid or high-volume infusions, in the region of a preexisting mass, such as a tumor, could induce herniation with its attendant serious effects. Despite these concerns, irreversible neurological deficits and significant intracranial pressure increases associated with convective delivery rarely occur in small animals, nonhuman primates, or humans (over 200-ml infusions into the brain in patients with brain tumors). ${ }^{49,81}$ If deficits occur, they rapidly reverse with the cessation of infusion and/or glucocorticoid administration.

Despite the well-defined safety of CED of therapeutics in the CNS, there have been reported cases of lasting or irreversible neurological changes in animal studies and human clinical trials. ${ }^{2,44,49,71}$ These neurological changes have been attributed to prolonged edema or effects of the drug on tumor (in tumor-specific trials and/or the putative therapeutic infused at doses in a potentially tissue toxic range). Lasting or irreversible neurological changes directly attributed to the convective infusion of substances in the CNS have not occurred over a range of infusate rates, including rates up to $10 \mu \mathrm{l} / \mathrm{min}$.

\section{Clearance of Solutes After CED}

During the postinfusion phase, solute (particularly small molecules) continues to redistribute, both via natural bulk flow and diffusion. However, as a result of continuing local clearance of the infusate, diffusional expansion of the perfused region is limited for most agents. ${ }^{69}$ Further, because of the square-shaped distribution curve associated with most CED protocols, postinfusion diffusion is confined to the steep edge of the distribution, and this generally contributes negligible extension to the tissue penetration depth already achieved at the end of the infusion proper. Only in the case of small infusion volumes would such diffusion significantly increase the tissue distribution volume.

\section{Clinical Application of Convective Delivery Convective Delivery Paradigms}

Targeted Therapeutics

A number of new targeted therapeutics have been developed to address a wide variety of neurological disor- 
ders. The properties of CED are being exploited to deliver these therapeutic agents to site-specific regions of the CNS to investigate a variety of disorders that are currently untreatable or cannot be addressed using other available CNS drug delivery methods. Ideal agents for delivery by convection include those that are pathology selective, have a targeted CNS region for application, are metabolized at rates that permit them to be therapeutic, and do not effectively cross the BBB. Therapeutic approaches can selectively lesion or augment diseased CNS cell populations, regulate abnormal metabolic disease pathways, transiently alleviate pathophysiology, and/or target tumor cells for selective destruction. Neurological disorders and agents that have been investigated using CED are described in Table 1.

\section{Physiological Manipulation}

The ability to transiently augment or suppress the activity of targeted components of diseased neuronal circuits by selectively delivering neuroactive compounds presents a new opportunity to derive deeper insight into disease pathophysiology. Specifically, the ability to directly correlate the effects of the physiological manipulation of diseased brain structures with clinical effects represents an opportunity for understanding mechanisms of disease, introducing new methods of diagnosis, developing new treatments, as well as introducing and using new therapeutic agents. There are immediate opportunities to better understand disorders that have site-specific pathophysiological features, including Parkinson's disease, essential tremor, obesity, anorexia nervosa, epilepsy, and behavioral disorders. ${ }^{32,50,79}$

\section{Future of Real-Time Imaging to Clinical Treatment Paradigm}

Previously, CED using new putative therapeutic agents was clinically applied in isolated cases or Phase I/II trials (Table 1). The only CED Phase III trial performed to date involved the infusion of the glioma toxin interleukin-13 bound to Pseudomonas exotoxin in patients with glioblastoma multiforme. ${ }^{43}$ This treatment did not show a significant increase in patient survival compared with treatment with bis-chloroethylnitrosourea (BCNU)-impregnated Gliadel wafers. Because real-time imaging of co-infused surrogate MRI agents was not used routinely and drug distribution could not be accurately established, coverage of the targeted tissues was not confirmed. Moreover, in most of the clinical trials, the investigation has combined a new (experimental) therapeutic agent with CED, a new drug delivery approach. The advantages and limitations of convective delivery in various clinical circumstances, as well as the efficacy of various agents, are not known. ${ }^{43,49,94,96}$ These circumstances underscore the need for real-time imaging of drug distribution, or surrogates of drug distribution, during CED in clinical studies and/or applications to verify targeting.

With improved CED procedures and infusion systems, emerging clinical data from real-time imaging has demonstrated that CED can treat clinically relevant regions and volumes in a targeted manner. Further, these early
TABLE 1. Convective delivery for the treatment of neurological disorders

\begin{tabular}{|c|c|c|}
\hline Disorder & Therapeutic Agent & References \\
\hline \multicolumn{3}{|l|}{ Metabolic disorder } \\
\hline $\begin{array}{l}\text { Neuronal ceroid } \\
\text { lipofuscinosis }\end{array}$ & AAV-CLN2 cDNA & $23,104,117$ \\
\hline AADC deficiency & AAV-AADC & 34 \\
\hline Gaucher disease & Glucocerebrosidase & 59 \\
\hline \multicolumn{3}{|l|}{$\begin{array}{l}\text { Neurodegenerative } \\
\text { disease }\end{array}$} \\
\hline \multirow[t]{4}{*}{ Parkinson disease } & GDNF & $28,46,82$ \\
\hline & AAV-CNTF & 64,65 \\
\hline & AAV-GAD & 37,51 \\
\hline & AAV-AADC & $19,26,66,73$ \\
\hline \multicolumn{3}{|l|}{ Neurooncology } \\
\hline \multirow{6}{*}{$\begin{array}{l}\text { Glioblastoma multi- } \\
\text { forme }\end{array}$} & Chemotherapeutics & $8,10,52,84,96,107,115$ \\
\hline & Viral-based agent & 110 \\
\hline & Targeted toxins & $43,45,49,94,95,97,109,111-113$ \\
\hline & Liposome carrier & 87 \\
\hline & Radio-immunotherapy & 30,83 \\
\hline & Immunotherapy & 11,12 \\
\hline \multirow{2}{*}{$\begin{array}{l}\text { Diffuse intrinsic } \\
\text { pontine glioma }\end{array}$} & Targeted toxin & 62 \\
\hline & Chemotherapeutics & $2,4,92$ \\
\hline
\end{tabular}

$\mathrm{AADC}=$ aromatic L-amino acid decarboxylase; $\mathrm{AAV}=$ adeno-associated virus; CLN2 = neuronal ceroid lipofuscinoses; CNTF = ciliary neurotrophic factor;

$\mathrm{GAD}=$ glutamic acid decarboxylase; $\mathrm{GDNF}$ = glial-derived neurotrophic factor.

clinical data underscore the properties described in preclinical studies, enhance safety by permitting controlled distribution, and give direct insight into therapeutic efficacy. Moreover, data from real-time imaging of convective delivery in the CNS provide understanding of the properties of CED in various clinical circumstances. Specifically, critical information about the optimal infusion rate, effect of pial/ependymal surfaces, effect of previous surgery, vasogenic edema (when present), and preferred pathways of infusate flow can be derived from these studies.

\section{Limitations of CED}

While there are a number of advantages of CED in distributing therapeutic compounds to the CNS, there are also potential limitations. First, because CED requires cannula placement, it is more invasive then systemic delivery techniques. Second, drugs that easily cross the BBB will probably not be good drugs to deliver via CED, as they can readily leak through the CNS vasculature and into the systemic circulation. Third, therapeutics that are rapidly metabolized or taken up by CNS cellular components may limit the spread of infusate. Finally, improved targeting technologies that account for anatomical boundaries (that is, ependymal surfaces, pial surfaces, resection cavities, gray-white junctions) or pathological structural changes (that is, vasogenic edema or necrotic areas) will alter infusate flow and distribution and require longer infusion or multiple cannula placements to achieve therapeutic infusate coverage. 


\section{Predictive Modeling for Clinical Application}

As the biomechanical principles of CED are better understood and confirmed via real-time imaging under a variety of pathological conditions, defined and accurate preclinical predictive modeling based on imaging should be feasible across a wide spectrum of neurological disease states. The ability to accurately predict optimal cannula placement and the capability to precisely anticipate infusate distribution based on preinfusion CT and MRI planning will be important for clinical trial development. ${ }^{40,55,56,89,102}$

\section{References}

1. Abbott NJ: Evidence for bulk flow of brain interstitial fluid: significance for physiology and pathology. Neurochem Int 45:545-552, 2004

2. Anderson RCE, Kennedy B, Yanes CL, Garvin J, Needle $\mathrm{M}$, Canoll P, et al: Convection-enhanced delivery of topotecan into diffuse intrinsic brainstem tumors in children. J Neurosurg Pediatr 11:289-295, 2013

3. Asthagiri AR, Walbridge S, Heiss JD, Lonser RR: Effect of concentration on the accuracy of convective imaging distribution of a gadolinium-based surrogate tracer. Laboratory investigation. J Neurosurg 115:467-473, 2011

4. Barua NU, Lowis SP, Woolley M, O'Sullivan S, Harrison R, Gill SS: Robot-guided convection-enhanced delivery of carboplatin for advanced brainstem glioma. Acta Neurochir (Wien) 155: 1459-1465, 2013

5. Basser PJ: Interstitial pressure, volume, and flow during infusion into brain tissue. Microvasc Res 44: 143-165, 1992

6. Blasberg RG, Patlak C, Fenstermacher JD: Intrathecal chemotherapy: brain tissue profiles after ventriculocisternal perfusion. J Pharmacol Exp Ther 195:73-83, 1975

7. Bobo RH, Laske DW, Akbasak A, Morrison PF, Dedrick RL, Oldfield EH: Convection-enhanced delivery of macromolecules in the brain. Proc Natl Acad Sci U S A 91:2076-2080, 1994

8. Bogdahn U, Hau P, Stockhammer G, Venkataramana NK, Mahapatra AK, Suri A, et al: Targeted therapy for highgrade glioma with the TGF- $\beta 2$ inhibitor trabedersen: results of a randomized and controlled phase IIb study. Neuro Oncol 13:132-142, 2011

9. Bruce JN, Falavigna A, Johnson JP, Hall JS, Birch BD, Yoon JT, et al: Intracerebral clysis in a rat glioma model. Neurosurgery 46:683-691, 2000

10. Bruce JN, Fine RL, Canoll P, Yun J, Kennedy BC, Rosenfeld SS, et al: Regression of recurrent malignant gliomas with convection-enhanced delivery of topotecan. Neurosurgery 69:1272-1280, 2011

11. Carpentier A, Laigle-Donadey F, Zohar S, Capelle L, Behin A, Tibi A, et al: Phase 1 trial of a $\mathrm{CpG}$ oligodeoxynucleotide for patients with recurrent glioblastoma. Neuro Oncol 8:60-66, 2006

12. Carpentier A, Metellus P, Ursu R, Zohar S, Lafitte F, Barrié $\mathrm{M}$, et al: Intracerebral administration of $\mathrm{CpG}$ oligonucleotide for patients with recurrent glioblastoma: a phase II study. Neuro Oncol 12:401-408, 2010

13. Chen MY, Hoffer A, Morrison PF, Hamilton JF, Hughes J, Schlageter KS, et al: Surface properties, more than size, limiting convective distribution of virus-sized particles and viruses in the central nervous system. J Neurosurg 103:311-319, 2005

14. Chen MY, Lonser RR, Morrison PF, Governale LS, Oldfield EH: Variables affecting convection-enhanced delivery to the striatum: a systematic examination of rate of infusion, cannula size, infusate concentration, and tissuecannula sealing time. J Neurosurg 90:315-320, 1999
15. Chen PY, Ozawa T, Drummond DC, Kalra A, Fitzgerald JB, Kirpotin DB, et al: Comparing routes of delivery for nanoliposomal irinotecan shows superior anti-tumor activity of local administration in treating intracranial glioblastoma xenografts. Neuro Oncol 15:189-197, 2013

16. Chen X, Astary GW, Mareci TH, Sarntinoranont M: In vivo contrast-enhanced MR imaging of direct infusion into rat peripheral nerves. Ann Biomed Eng 39:2823-2834, 2011

17. Chen X, Sarntinoranont M: Biphasic finite element model of solute transport for direct infusion into nervous tissue. Ann Biomed Eng 35:2145-2158, 2007

18. Chittiboina P, Heiss JD, Warren KE, Lonser RR: Magnetic resonance imaging properties of convective delivery in diffuse intrinsic pontine gliomas. Clinical article. J Neurosurg Pediatr 13:276-282, 2014

19. Christine CW, Starr PA, Larson PS, Eberling JL, Jagust WJ, Hawkins RA, et al: Safety and tolerability of putaminal AADC gene therapy for Parkinson disease. Neurology 73:1662-1669, 2009

20. Ciesielska A, Mittermeyer G, Hadaczek P, Kells AP, Forsayeth J, Bankiewicz KS: Anterograde axonal transport of AAV2-GDNF in rat basal ganglia. Mol Ther 19:922927, 2011

21. Corem-Salkmon E, Ram Z, Daniels D, Perlstein B, Last $\mathrm{D}$, Salomon S, et al: Convection-enhanced delivery of methotrexate-loaded maghemite nanoparticles. Int J Nanomedicine 6:1595-1602, 2011

22. Croteau D, Walbridge S, Morrison PF, Butman JA, Vortmeyer AO, Johnson D, et al: Real-time in vivo imaging of the convective distribution of a low-molecular-weight tracer. J Neurosurg 102:90-97, 2005

23. Crystal RG, Sondhi D, Hackett NR, Kaminsky SM, Worgall S, Stieg P, et al: Clinical protocol. Administration of a replication-deficient adeno-associated virus gene transfer vector expressing the human CLN2 cDNA to the brain of children with late infantile neuronal ceroid lipofuscinosis. Hum Gene Ther 15:1131-1154, 2004

24. Dickinson PJ, LeCouteur RA, Higgins RJ, Bringas JR, Roberts B, Larson RF, et al: Canine model of convectionenhanced delivery of liposomes containing CPT-11 monitored with real-time magnetic resonance imaging. Laboratory investigation. J Neurosurg 108:989-998, 2008

25. Ding D, Kanaly CW, Bigner DD, Cummings TJ, Herndon JE II, Pastan I, et al: Convection-enhanced delivery of free gadolinium with the recombinant immunotoxin MR1-1. J Neurooncol 98:1-7, 2010 (Erratum in J Neurooncol 98:17, 2010)

26. Eberling JL, Jagust WJ, Christine CW, Starr P, Larson P, Bankiewicz KS, et al: Results from a phase I safety trial of hAADC gene therapy for Parkinson disease. Neurology 70:1980-1983, 2008

27. Fiandaca MS, Varenika V, Eberling J, McKnight T, Bringas J, Pivirotto P, et al: Real-time MR imaging of adeno-associated viral vector delivery to the primate brain. Neuroimage 47 (Suppl 2):T27-T35, 2009

28. Gill SS, Patel NK, Hotton GR, O’Sullivan K, McCarter R, Bunnage M, et al: Direct brain infusion of glial cell linederived neurotrophic factor in Parkinson disease. Nat Med 9:589-595, 2003

29. Haar PJ, Broaddus WC, Chen ZJ, Fatouros PP, Gillies GT, Corwin FD: Gd-DTPA T1 relaxivity in brain tissue obtained by convection-enhanced delivery, magnetic resonance imaging and emission spectroscopy. Phys Med Biol 55:34513465,2010

30. Hdeib A, Sloan AE: Convection-enhanced delivery of 131I-chTNT-1/B mAB for treatment of high-grade adult gliomas. Expert Opin Biol Ther 11:799-806, 2011

31. Heiss JD, Walbridge S, Asthagiri AR, Lonser RR: Imageguided convection-enhanced delivery of muscimol to the 
primate brain. Laboratory investigation. J Neurosurg 112:790-795, 2010

32. Heiss JD, Walbridge S, Morrison P, Hampton RR, Sato S, Vortmeyer A, et al: Local distribution and toxicity of prolonged hippocampal infusion of muscimol. J Neurosurg 103:1035-1045, 2005

33. Huynh NT, Passirani C, Allard-Vannier E, Lemaire L, Roux $\mathrm{J}$, Garcion E, et al: Administration-dependent efficacy of ferrociphenol lipid nanocapsules for the treatment of intracranial 9L rat gliosarcoma. Int J Pharm 423:55-62, 2012

34. Hwu WL, Muramatsu S, Tseng SH, Tzen KY, Lee NC, Chien YH, et al: Gene therapy for aromatic L-amino acid decarboxylase deficiency. Sci Transl Med 4:134ra161, 2012

35. Iyer RR, Butman JA, Walbridge S, Gai ND, Heiss JD, Lonser RR: Tracking accuracy of T2- and diffusion-weighted magnetic resonance imaging for infusate distribution by convection-enhanced delivery. Laboratory investigation. J Neurosurg 115:474-480, 2011

36. Jagannathan J, Walbridge S, Butman JA, Oldfield EH, Lonser RR: Effect of ependymal and pial surfaces on convection-enhanced delivery. Laboratory investigation. J Neurosurg 109:547-552, 2008

37. Kaplitt MG, Feigin A, Tang C, Fitzsimons HL, Mattis P, Lawlor PA, et al: Safety and tolerability of gene therapy with an adeno-associated virus (AAV) borne GAD gene for Parkinson's disease: an open label, phase I trial. Lancet 369:2097-2105, 2007

38. Kells AP, Hadaczek P, Yin D, Bringas J, Varenika V, Forsayeth J, et al: Efficient gene therapy-based method for the delivery of therapeutics to primate cortex. Proc Natl Acad Sci U S A 106:2407-2411, 2009

39. Kim JH, Astary GW, Chen X, Mareci TH, Sarntinoranont M: Voxelized model of interstitial transport in the rat spinal cord following direct infusion into white matter. J Biomech Eng 131:071007, 2009

40. Kim JH, Astary GW, Kantorovich S, Mareci TH, Carney PR, Sarntinoranont M: Voxelized computational model for convection-enhanced delivery in the rat ventral hippocampus: comparison with in vivo MR experimental studies. Ann Biomed Eng 40:2043-2058, 2012

41. Krauze MT, Saito R, Noble C, Tamas M, Bringas J, Park JW, et al: Reflux-free cannula for convection-enhanced high-speed delivery of therapeutic agents. Technical note. J Neurosurg 103:923-929, 2005

42. Ksendzovsky A, Walbridge S, Saunders RC, Asthagiri AR, Heiss JD, Lonser RR: Convection-enhanced delivery of M13 bacteriophage to the brain. Laboratory investigation. J Neurosurg 117:197-203, 2012

43. Kunwar S, Chang S, Westphal M, Vogelbaum M, Sampson J, Barnett G, et al: Phase III randomized trial of CED of IL13-PE38QQR vs Gliadel wafers for recurrent glioblastoma. Neuro Oncol 12:871-881, 2010

44. Kunwar S, Chang SM, Prados MD, Berger MS, Sampson JH, Croteau D, et al: Safety of intraparenchymal convection-enhanced delivery of cintredekin besudotox in earlyphase studies. Neurosurg Focus 20(4):E15, 2006

45. Kunwar S, Prados MD, Chang SM, Berger MS, Lang FF, Piepmeier JM, et al: Direct intracerebral delivery of cintredekin besudotox (IL13-PE38QQR) in recurrent malignant glioma: a report by the Cintredekin Besudotox Intraparenchymal Study Group. J Clin Oncol 25:837-844, 2007

46. Lang AE, Gill S, Patel NK, Lozano A, Nutt JG, Penn R, et al: Randomized controlled trial of intraputamenal glial cell line-derived neurotrophic factor infusion in Parkinson disease. Ann Neurol 59:459-466, 2006

47. Langer R: New methods of drug delivery. Science 249: $1527-1533,1990$

48. Laske DW, Morrison PF, Lieberman DM, Corthesy ME, Reynolds JC, Stewart-Henney PA, et al: Chronic interstitial infusion of protein to primate brain: determination of drug distribution and clearance with single-photon emission computerized tomography imaging. J Neurosurg 87:586-594, 1997

49. Laske DW, Youle RJ, Oldfield EH: Tumor regression with regional distribution of the targeted toxin TF-CRM107 in patients with malignant brain tumors. Nat Med 3:13621368,1997

50. Levy R, Lang AE, Dostrovsky JO, Pahapill P, Romas J, Saint-Cyr J, et al: Lidocaine and muscimol microinjections in subthalamic nucleus reverse Parkinsonian symptoms. Brain 124:2105-2118, 2001

51. LeWitt PA, Rezai AR, Leehey MA, Ojemann SG, Flaherty AW, Eskandar EN, et al: AAV2-GAD gene therapy for advanced Parkinson's disease: a double-blind, sham-surgery controlled, randomised trial. Lancet Neurol 10:309-319, 2011

52. Lidar Z, Mardor Y, Jonas T, Pfeffer R, Faibel M, Nass D, et al: Convection-enhanced delivery of paclitaxel for the treatment of recurrent malignant glioma: a phase I/II clinical study. J Neurosurg 100:472-479, 2004

53. Lieberman DM, Corthesy ME, Cummins A, Oldfield EH: Reversal of experimental parkinsonism by using selective chemical ablation of the medial globus pallidus. J Neurosurg 90:928-934, 1999

54. Lieberman DM, Laske DW, Morrison PF, Bankiewicz KS, Oldfield EH: Convection-enhanced distribution of large molecules in gray matter during interstitial drug infusion. $\mathbf{J}$ Neurosurg 82:1021-1029, 1995

55. Linninger AA, Somayaji MR, Erickson T, Guo X, Penn RD: Computational methods for predicting drug transport in anisotropic and heterogeneous brain tissue. J Biomech 41:2176-2187, 2008

56. Linninger AA, Somayaji MR, Mekarski M, Zhang L: Prediction of convection-enhanced drug delivery to the human brain. J Theor Biol 250:125-138, 2008

57. Lonser RR, Corthésy ME, Morrison PF, Gogate N, Oldfield $\mathrm{EH}$ : Convection-enhanced selective excitotoxic ablation of the neurons of the globus pallidus internus for treatment of parkinsonism in nonhuman primates. J Neurosurg 91:294302, 1999

58. Lonser RR, Gogate N, Morrison PF, Wood JD, Oldfield EH: Direct convective delivery of macromolecules to the spinal cord. J Neurosurg 89:616-622, 1998

59. Lonser RR, Schiffman R, Robison RA, Butman JA, Quezado Z, Walker ML, et al: Image-guided, direct convective delivery of glucocerebrosidase for neuronopathic Gaucher disease. Neurology 68:254-261, 2007

60. Lonser RR, Walbridge S, Garmestani K, Butman JA, Walters HA, Vortmeyer AO, et al: Successful and safe perfusion of the primate brainstem: in vivo magnetic resonance imaging of macromolecular distribution during infusion. J Neurosurg 97:905-913, 2002

61. Lonser RR, Walbridge S, Murray GJ, Aizenberg MR, Vortmeyer AO, Aerts JM, et al: Convection perfusion of glucocerebrosidase for neuronopathic Gaucher's disease. Ann Neurol 57:542-548, 2005

62. Lonser RR, Warren KE, Butman JA, Quezado Z, Robison RA, Walbridge $S$, et al: Real-time image-guided direct convective perfusion of intrinsic brainstem lesions. Technical note. J Neurosurg 107:190-197, 2007

63. Lonser RR, Weil RJ, Morrison PF, Governale LS, Oldfield EH: Direct convective delivery of macromolecules to peripheral nerves. J Neurosurg 89:610-615, 1998

64. Marks WJ Jr, Bartus RT, Siffert J, Davis CS, Lozano A, Boulis N, et al: Gene delivery of AAV2-neurturin for Parkinson's disease: a double-blind, randomised, controlled trial. Lancet Neurol 9:1164-1172, 2010

65. Marks WJ Jr, Ostrem JL, Verhagen L, Starr PA, Larson PS, 
Bakay RA, et al: Safety and tolerability of intraputaminal delivery of CERE-120 (adeno-associated virus serotype 2-neurturin) to patients with idiopathic Parkinson's disease: an open-label, phase I trial. Lancet Neurol 7:400-408, 2008

66. Mittermeyer G, Christine CW, Rosenbluth KH, Baker SL, Starr P, Larson P, et al: Long-term evaluation of a phase 1 study of AADC gene therapy for Parkinson's disease. Hum Gene Ther 23:377-381, 2012

67. Morrison PF: Distributed models of drug kinetics, in Atkinson AJ Jr, Huang SM, Lertora JJL, et al (eds): Principles of Clinical Pharmacology. San Diego: Academic Press, 2001, pp 117-138

68. Morrison PF, Chen MY, Chadwick RS, Lonser RR, Oldfield EH: Focal delivery during direct infusion to brain: role of flow rate, catheter diameter, and tissue mechanics. Am J Physiol 277:R1218-R1229, 1999

69. Morrison PF, Laske DW, Bobo H, Oldfield EH, Dedrick RL: High-flow microinfusion: tissue penetration and pharmacodynamics. Am J Physiol 266:R292-R305, 1994

70. Morrison PF, Lonser RR, Oldfield EH: Convective delivery of glial cell line-derived neurotrophic factor in the human putamen. J Neurosurg 107:74-83, 2007

71. Murad GJA, Walbridge S, Morrison PF, Garmestani K, Degen JW, Brechbiel MW, et al: Real-time, image-guided, convection-enhanced delivery of interleukin 13 bound to pseudomonas exotoxin. Clin Cancer Res 12:3145-3151, 2006

72. Murad GJA, Walbridge S, Morrison PF, Szerlip N, Butman JA, Oldfield EH, et al: Image-guided convection-enhanced delivery of gemcitabine to the brainstem. J Neurosurg 106:351-356, 2007

73. Muramatsu S, Fujimoto K, Kato S, Mizukami H, Asari S, Ikeguchi K, et al: A phase I study of aromatic L-amino acid decarboxylase gene therapy for Parkinson's disease. Mol Ther 18:1731-1735, 2010

74. Nduom EK, Walbridge S, Lonser RR: Comparison of pulsed versus continuous convective flow for central nervous system tissue perfusion. Laboratory investigation. J Neurosurg 117:1150-1154, 2012

75. Neeves KB, Sawyer AJ, Foley CP, Saltzman WM, Olbricht WL: Dilation and degradation of the brain extracellular matrix enhances penetration of infused polymer nanoparticles. Brain Res 1180:121-132, 2007

76. Nguyen TT, Pannu YS, Sung C, Dedrick RL, Walbridge S, Brechbiel MW, et al: Convective distribution of macromolecules in the primate brain demonstrated using computerized tomography and magnetic resonance imaging. J Neurosurg 98:584-590, 2003

77. Oh S, Odland R, Wilson SR, Kroeger KM, Liu C, Lowenstein PR, et al: Improved distribution of small molecules and viral vectors in the murine brain using a hollow fiber catheter. J Neurosurg 107:568-577, 2007

78. Oh S, Ohlfest JR, Todhunter DA, Vallera VD, Hall WA, Chen $\mathrm{H}$, et al: Intracranial elimination of human glioblastoma brain tumors in nude rats using the bispecific liganddirected toxin, DTEGF13 and convection enhanced delivery. J Neurooncol 95:331-342, 2009

79. Pahapill PA, Levy R, Dostrovsky JO, Davis KD, Rezai AR, Tasker RR, et al: Tremor arrest with thalamic microinjections of muscimol in patients with essential tremor. Ann Neurol 46:249-252, 1999

80. Pardridge WM: Drug delivery to the brain. J Cereb Blood Flow Metab 17:713-731, 1997

81. Parney IF, Kunwar S, McDermott M, Berger M, Prados M, Cha S, et al: Neuroradiographic changes following convection-enhanced delivery of the recombinant cytotoxin interleukin 13-PE38QQR for recurrent malignant glioma. J Neurosurg 102:267-275, 2005
82. Patel NK, Bunnage M, Plaha P, Svendsen CN, Heywood P, Gill SS: Intraputamenal infusion of glial cell line-derived neurotrophic factor in PD: a two-year outcome study. Ann Neurol 57:298-302, 2005

83. Patel SJ, Shapiro WR, Laske DW, Jensen RL, Asher AL, Wessels BW, et al: Safety and feasibility of convectionenhanced delivery of Cotara for the treatment of malignant glioma: initial experience in 51 patients. Neurosurgery 56:1243-1253, 2005

84. Pöpperl G, Goldbrunner R, Gildehaus FJ, Kreth FW, Tanner P, Holtmannspötter M, et al: O-(2-[18F]fluoroethyl)-L-tyrosine PET for monitoring the effects of convection-enhanced delivery of paclitaxel in patients with recurrent glioblastoma. Eur J Nucl Med Mol Imaging 32:1018-1025, 2005

85. Raghavan R, Mikaelian S, Brady M, Chen ZJ: Fluid infusions from catheters into elastic tissue: I. Azimuthally symmetric backflow in homogeneous media. Phys Med Biol 55:281-304, 2010

86. Rapoport SI, Thompson HK: Osmotic opening of the bloodbrain barrier in the monkey without associated neurological deficits. Science 180:971, 1973

87. Ren H, Boulikas T, Lundstrom K, Söling A, Warnke PC, Rainov NG: Immunogene therapy of recurrent glioblastoma multiforme with a liposomally encapsulated replicationincompetent Semliki forest virus vector carrying the human interleukin-12 gene-a phase I/II clinical protocol. J Neurooncol 64:147-154, 2003

88. Richardson RM, Gimenez F, Salegio EA, Su X, Bringas $\mathrm{J}$, Berger MS, et al: T2 imaging in monitoring of intraparenchymal real-time convection-enhanced delivery. Neurosurgery 69:154-163, 2011

89. Rosenbluth KH, Eschermann JF, Mittermeyer G, Thomson R, Mittermeyer S, Bankiewicz KS: Analysis of a simulation algorithm for direct brain drug delivery. Neuroimage 59:2423-2429, 2012

90. Rosenbluth KH, Luz M, Mohr E, Mittermeyer S, Bringas J, Bankiewicz KS: Design of an in-dwelling cannula for convection-enhanced delivery. J Neurosci Methods 196:118123,2011

91. Rosenbluth KH, Martin AJ, Bringas J, Bankiewicz KS: Evaluation of pressure-driven brain infusions in nonhuman primates by intra-operative 7 Tesla MRI. J Magn Reson Imaging 36:1339-1346, 2012

92. Saito R, Sonoda Y, Kumabe T, Nagamatsu K, Watanabe M, Tominaga T: Regression of recurrent glioblastoma infiltrating the brainstem after convection-enhanced delivery of nimustine hydrochloride. J Neurosurg Pediatr 7:522-526, 2011

93. Salegio EA, Kells AP, Richardson RM, Hadaczek P, Forsayeth J, Bringas J, et al: Magnetic resonance imagingguided delivery of adeno-associated virus type 2 to the primate brain for the treatment of lysosomal storage disorders. Hum Gene Ther 21:1093-1103, 2010

94. Sampson JH, Akabani G, Archer GE, Berger MS, Coleman $\mathrm{RE}$, Friedman AH, et al: Intracerebral infusion of an EGFRtargeted toxin in recurrent malignant brain tumors. Neuro Oncol 10:320-329, 2008

95. Sampson JH, Akabani G, Archer GE, Bigner DD, Berger MS, Friedman AH, et al: Progress report of a Phase I study of the intracerebral microinfusion of a recombinant chimeric protein composed of transforming growth factor (TGF)alpha and a mutated form of the Pseudomonas exotoxin termed PE-38 (TP-38) for the treatment of malignant brain tumors. J Neurooncol 65:27-35, 2003

96. Sampson JH, Archer G, Pedain C, Wembacher-Schröder E, Westphal M, Kunwar S, et al: Poor drug distribution as a possible explanation for the results of the PRECISE trial. Clinical article. J Neurosurg 113:301-309, 2010

97. Sampson JH, Brady M, Raghavan R, Mehta AI, Friedman 
$\mathrm{AH}$, Reardon DA, et al: Colocalization of gadolinium-diethylene triamine pentaacetic acid with high-molecular-weight molecules after intracerebral convection-enhanced delivery in humans. Neurosurgery 69:668-676, 2011

98. Sampson JH, Raghavan R, Provenzale JM, Croteau D, Reardon DA, Coleman RE, et al: Induction of hyperintense signal on T2-weighted MR images correlates with infusion distribution from intracerebral convection-enhanced delivery of a tumor-targeted cytotoxin. AJR Am J Roentgenol 188:703-709, 2007

99. Sandberg DI, Edgar MA, Souweidane MM: Convectionenhanced delivery into the rat brainstem. J Neurosurg 96:885-891, 2002

100. Sarntinoranont M, Banerjee RK, Lonser RR, Morrison PF: A computational model of direct interstitial infusion of macromolecules into the spinal cord. Ann Biomed Eng 31:448-461, 2003

101. Sarntinoranont M, Chen X, Zhao J, Mareci TH: Computational model of interstitial transport in the spinal cord using diffusion tensor imaging. Ann Biomed Eng 34:1304-1321, 2006

102. Sarntinoranont M, Iadarola MJ, Lonser RR, Morrison PF: Direct interstitial infusion of NK1-targeted neurotoxin into the spinal cord: a computational model. Am J Physiol Regul Integr Comp Physiol 285:R243-R254, 2003

103. Smith JH, García JJ: A nonlinear biphasic model of flowcontrolled infusions in brain: mass transport analyses. $\mathbf{J}$ Biomech 44:524-531, 2011

104. Souweidane MM, Fraser JF, Arkin LM, Sondhi D, Hackett NR, Kaminsky SM, et al: Gene therapy for late infantile neuronal ceroid lipofuscinosis: neurosurgical considerations. J Neurosurg Pediatr 6:115-122, 2010

105. Strasser JF, Fung LK, Eller S, Grossman SA, Saltzman WM: Distribution of 1,3-bis(2-chloroethyl)-1-nitrosourea and tracers in the rabbit brain after interstitial delivery by biodegradable polymer implants. J Pharmacol Exp Ther 275:1647-1655, 1995

106. Szerlip NJ, Walbridge S, Yang L, Morrison PF, Degen JW, Jarrell ST, et al: Real-time imaging of convection-enhanced delivery of viruses and virus-sized particles. J Neurosurg 107:560-567, 2007

107. Tanner PG, Holtmannspötter M, Tonn JC, Goldbrunner R: Effects of drug efflux on convection-enhanced paclitaxel delivery to malignant gliomas: technical note. Neurosurgery 61:E880-E882, 2007

108. Thorne RG, Nicholson C: In vivo diffusion analysis with quantum dots and dextrans predicts the width of brain extracellular space. Proc Natl Acad Sci U S A 103:5567-5572, 2006

109. Vogelbaum MA, Sampson JH, Kunwar S, Chang SM, Shaffrey M, Asher AL, et al: Convection-enhanced delivery of cintredekin besudotox (interleukin-13-PE38QQR) followed by radiation therapy with and without temozolomide in newly diagnosed malignant gliomas: phase 1 study of final safety results. Neurosurgery 61:1031-1038, 2007
110. Voges J, Reszka R, Gossmann A, Dittmar C, Richter R, Garlip G, et al: Imaging-guided convection-enhanced delivery and gene therapy of glioblastoma. Ann Neurol 54:479487, 2003

111. Weaver M, Laske DW: Transferrin receptor ligand-targeted toxin conjugate (Tf-CRM107) for therapy of malignant gliomas. J Neurooncol 65:3-13, 2003

112. Weber F, Asher A, Bucholz R, Berger M, Prados M, Chang S, et al: Safety, tolerability, and tumor response of IL4Pseudomonas exotoxin (NBI-3001) in patients with recurrent malignant glioma. J Neurooncol 64:125-137, 2003

113. Weber FW, Floeth F, Asher A, Bucholz R, Berger M, Prados M, et al: Local convection enhanced delivery of IL4Pseudomonas exotoxin (NBI-3001) for treatment of patients with recurrent malignant glioma. Acta Neurochir Suppl 88:93-103, 2003

114. White E, Bienemann A, Malone J, Megraw L, Bunnun C, Wyatt M, et al: An evaluation of the relationships between catheter design and tissue mechanics in achieving highflow convection-enhanced delivery. J Neurosci Methods 199:87-97, 2011

115. White E, Bienemann A, Taylor H, Hopkins K, Cameron A, Gill S: A phase I trial of carboplatin administered by convection-enhanced delivery to patients with recurrent/ progressive glioblastoma multiforme. Contemp Clin Trials 33:320-331, 2012

116. Wood JD, Lonser RR, Gogate N, Morrison PF, Oldfield $\mathrm{EH}$ : Convective delivery of macromolecules into the naive and traumatized spinal cords of rats. J Neurosurg 90 (1 Suppl):115-120, 1999

117. Worgall S, Sondhi D, Hackett NR, Kosofsky B, Kekatpure MV, Neyzi N, et al: Treatment of late infantile neuronal ceroid lipofuscinosis by CNS administration of a serotype 2 adeno-associated virus expressing CLN2 cDNA. Hum Gene Ther 19:463-474, 2008

\section{Author Contributions}

Conception and design: Lonser, Sarntinoranont, Oldfield. Acquisition of data: all authors. Analysis and interpretation of data: Sarntinoranont, Morrison, Oldfield. Drafting the article: all authors. Critically revising the article: all authors. Reviewed submitted version of manuscript: all authors. Approved the final version of the manuscript on behalf of all authors: Lonser. Administrative/technical/material support: Lonser.

\section{Correspondence}

Russell R. Lonser, Department of Neurological Surgery, The Ohio State University Wexner Medical Center, 410 W. 10th Ave., Doan Hall N1047, Columbus, OH 43210. email: russell. lonser@osumc.edu. 